SOCIAL PHILOSOPHY AND PHILOSOPHY OF HISTORY

UDC 159.923:796:316.22

DOI https://doi.org/10.30839/2072-7941.2018.155549

\title{
SELF-REALISATION OF PERSONALITY IN SPORT AS THE MAIN MEGATREND OF SPORT FORMATION PARADIGM IN CONDITIONS OF GLOBALIZATION: SOCIOANTHROPOLOGICAL MEASUREMENTS
}

\author{
(C) BILOHUR, V. E. \\ Melitopol State Pedagogical University named after Bohdan Khmelnitsky \\ (Melitopol, Ukraine) \\ E-mail: bilovlada@gmail.com, ORCID: 0000-0001-9041-7050
}

\begin{abstract}
Relevance of the research problem of self-realization of personality in sport as the main megatrend is specific feature of globalization, in the context of which the socioanthropological dimensions related to a person are not well-researched. This problem arises because it begins to rethink the phenomena of the man as a subject of sports activities. At the same time, the sport paradigm in conditions of globalization begins to re-think, according to its pros and cons. The purpose of the research is conceptualization of personality selfrealization in sport as the main megatrend of global society in context of socioanthropological measurements. Objectives of the research: study of sports management, determined by large-scale transformations of modern society; the study of principles on the basis of which the formation of sports paradigm under the conditions of globalization occurs; analysis of the realization of self-development possibilities of a person in the sports world in conditions of globalization; the formation of a new sports paradigm, which allows you to identify extent correlation of trends in sport and the development of human's essential forces as their generic entity. Analysis of recent researches and publications, which initiated the solution of this problem: use of articles by authors Vizitei N. (1986), Voronkova, V. (2015), Edensor, T. (2002), Hambrecht, H (2012), Holowchak , M., Reid H. (2011), Mechikoff, R. (2006), Morgan, W (2003), Olexenko, R. (2017), Scott, R. (2005), in which human problems and their self-actualization are solved in the sport world and socioanthropological principles that poorly found in sport field. The methodology of the research is anthropological and socio-axiological methods that contribute to the penetration of sportsman into the world, the evolution of a sports paradigm under the conditions of globalization, marked by many human-dimensional problems, since sport is also associated with commercialization. Scientific novelty - in identifying the problems of globalization affecting sports people, sports activities and the world of sport in general. Results of the research: Human self-realization in sport in the conditions of globalization, representing a qualitative characteristic of the sports world, started by various sporting practices of the sports world and reveals the movement towards integration and integrity. Conclusion - the endeavor of self-realization of personality in sport as the main megatrend of the formation of a sports paradigm in the conditions of globalization requires its addition to socio-anthropological measurements
\end{abstract}

Key words: self-realization of personality, megatrend, globalization, sport, sports management, sports paradigm, socio-anthropological measurements and human-dimensional sport.

Nation as a reflection of history, memory, language and culture 


\section{Problem solvency in general and its contacts with important scientific or practical tasks.}

Socio-anthropological dimensions of personality self-realization in sport as the main megatrend of globalization contribution, on the one hand, approximately modern sport to the limits of human-dimensionality, and, on the other, overcoming growth of threats associated with destructive phenomena in sport. These problems are studied by anthropology, the subject of which is a person as a special being and understanding the problems of human nature, modes of human existence, potential of anthropological picture of the world, in case of sports. This determines the relevance of the study analysis of recent researches and publications, which initiated solution of these problems, and according to the author, the allocation of previously unsolved parts of general problem, which is devoted to the article.

The problem, considered by globalization paradigm, helps to shape the world-view bases of human survival, thus accelerating the pace of its introduction and into sports practice. Globalization reveals a lot of examples of manifestation mechanisms of human survival under conditions of instability in anthropogenic socio-cultural systems. In this case, the work of Robertson, R., Walererstein, I., Giddens, E.,. Kastesels, M., Beck, U., Utkin A. and other researchers dedicated to the specialization of the phenomenon of globalization have made a significant contribution to the development of globalization. Under "globalization," many scholars understand the process in which the world is transformed into a single global system. In today's world, globalization of innovations, migration processes, science and education, political institutions, culture and sports is taking place.

The purpose of the research is the conceptualization of selfrealization of personality in sport as the main megatrend of a global society in the context of socioanthropological measurements.

Formation of the purposes of the article:

- study of the problems of sports management, determined by the largescale transformations of modern society;

- study of the principles on the basis of which the formation of a sports paradigm in the conditions of globalization;

- analysis of realization of possibilities of self-development of a person in the world of sports in the conditions of globalization;

- the formation of a new paradigm of sports paradigm, which allows you to identify the extent of the correlation of the trends in sport and the development of the essential forces of man as their generic entity.

Selection of previously unsettled parts of the general problem to which this article is devoted.

Self-realization of the person in sport as the main megatrend of global society is its transformation into global phenomena, universal human plan, which has significant influence on all aspects of people's lives in constellation with various phenomenon of society - existences, 
politics, economics, industry, personality development, leisure. Selfrealization of the person in sport contributes to the awareness of the interdependence of the world as a whole, in the center of which is the problem of self-improvement of the person, sports matrices and structures. All this leads to the formation of a paradigm of sport in the context of cultural culture of civilization as a paradigm of planetary scale sport that arises in the process of globalization. Representatives of globalization model a certain image of the future and accordingly seek to reconstruct the paradigm of sporting globalization. Globalization involves the transformation of sport and sports activities within the spatial organization of sports relationships and compromises that are characterized by intensity, speed and influence [1]. Moreover, in our opinion, the socio-anthropological foundations of self-realization of the person in sport as the main megatrend of the formation of a sports paradigm are not very knowledgeable.

\section{Presentation of the main research material with the justification of the received scientific results}

Self-realization of the individual in sports in the context of globalization today represents a qualitative characteristic of the sports world, which reveals a movement towards integration and integrity, manifested in all dimensions of being and human consciousness, means the formation of a community of social, economic, political, legal, sports relations. In different parts of the world, people react differently to global changes, because globalization can not only unite, but also divide people - and even through sport. All the above processes show that globalization is becoming the main paradigm of social development [1].

Management of sports in the context of globalization requires the formation of a sports paradigm that would cultivate a healthy personality and a healthy lifestyle, value-semantic parameters of the functioning of sports in higher institutions of Ukraine, a sports-oriented approach to learning, the development of physical and spiritual foundations of a sports personality, the creation of a fundamental new approach to physical education and sport. In the modern conditions of globalization, a structural transformation of the values of young people is taking place, so the solution to the problems associated with raising a healthy personality, which in the context of globalization is a social and humanitarian problem, should be put in the forefront [1].

In the arsenal of the globalization paradigm, sports policy is one of the priority directions of state policy, which is constantly changing due to its capabilities at the organizational, legislative, economic, social and cultural levels. It proceeds from the creation of the most favorable conditions for solving the problems of sports, supporting innovation in the field of sports, and improving conditions for the healthy sports development of an individual. Managing sports in the context of

Self-realisation of personality in sport as the main megatrend of sport formation paradigm in conditions of globalization: socioanthropological measurements 
globalization includes taking into account the characters, morals, traditions, customs of nations, cognitive models, and collisions of marginality.

Management of sports in the context of globalization is caused by large-scale transformations, which are determined by economic, political and cultural reasons. It is possible to create a modern sports paradigm in a market economy, without losing spiritual and professional approaches to the development of a sports personality, which requires combining the physical and spiritual components of the sports development paradigm, because sport has a great potential for developing and improving personality [4].

In the context of globalization, the institutionalization of sports is determined by the tendencies of orientation towards the professionalization and commercialization of sports, as a result of which sports are brought out of the physical and spiritual culture of an individual, focused on a more complete identification of its essential forces. Lately, tendencies of not only competitive, but also commercial strategy have emerged, in the context of which the final result loses connection with the development of the essential human forces, so harmony is lost between the humanistic essence of sports and those methods that are the basis for achieving the result, loss of humanity of sports as a social and match practice [2].

Globalization as the main paradigm of modern development is

associated with the features of modern era, which is central and largely unifying theme for natural science and humanitarian knowledge. Intensive integration of both commodity and service markets facilitates the definition of globalization as the intensification of world social relations, as a result of modernization, considering it in four institutional dimensions: 1) the world capitalist economy; 2) system of nation states; 3) world military order; 4) the international division of labor, which ultimately boils down world economy and politics. Globalization contributes the formation of micro-integrity, which belongs to the class of large systems [3].

Management of sports in the context of globalization contributes to the integration into the global economy and development of market relations for the early modernization and gaining high competitiveness. The economic foundations of globalization encounter not only political interests of national economies (protectionism), but also technical and economic restraints. Financial globalization has been greatly promoted by the development of information technology, which has made possible the functioning of global markets in real time and electronic funds transfer. Another important factor in economic globalization has been the development of transnational corporations, combining a significant increase in world trade in the last thirty years [4].

Cultural globalization is the result of mass tourism development, 
increased migration of population between societies, commercialization of cultural products and spread of consumerism throughout the world.

In context of globalization, transformation of sports into global, universal human plan takes place, which has significant impact on all aspects of people's lives. Sports globalization contributes to the awareness of the interdependence of the world as a whole. The globalization migration processes leading to a growing number of refugees, large-scale illegal migration, various forms of movement of people, and an increased demand for highly skilled labor. All this leads to the fact that globalism is emerging as a type of consciousness on a planetary scale that arises in the process of globalization [5].

Representatives of globalization model some image of the future and, accordingly, strive to pre-build society. Globalization invests social transformation in the framework of the spatial organization of social relations and trade-offs, which are characterized by their prevalence, intensity, speed and influence.

Globalism is today a qualitative characteristic of the modern world, which reveals a movement towards integration and integrity, manifested in all dimensions of being and human consciousness, means the formation of a community of social, economic, political, legal relations. In different parts of the world, people react differently to global changes: globalization can not only unite, but also divide people. Globalization potentially implies the possibility of complex regulation of global problems and the ability to make partial changes to the system. All the above processes show that globalization is becoming the main paradigm of social development, influencing the sports paradigm, contributing to the training of personnel for this sphere [6].

In the context of globalization, the management of sports highlights the principles on the basis of which the formation of the sports paradigm will occur: 1) principle of individualization, taking into account personal qualities, the needmotivational sphere in the development of sports, ability to sports; 2) principle of subjective development and self-development, expressed in the transformation of the installations received by the subject for the acquisition of internalized knowledge into an individual goal, promoting self-development in the process of achieving this goal; 3) principle of personalization of pedagogical interaction, involving cooperation in the process of sports education of students; 4) principle of reflexive process control of general and professional development, expressed in the fact that a systematic approach to the analysis of social and sports competence allows us to realize the dialectic and multidimensional nature of this process; 5) the principle of stimulating the process of goal setting, success and improvement, expressed in mental or actual diagnostics, correction of results, means of their achievement, belief in

Self-realisation of personality in sport as the main megatrend of sport formation paradigm in conditions of globalization: socioanthropological measurements 
success through the effective construction of a "hierarchy of goals"; 6) the principle of reliance on the methods of contextual and problemdialogue communication, which guarantees the introduction of the mechanism of unity of the humanistic, social and sports paradigm of education; 7) the principle of managing sports industry [9].

Sport is not only a social, but also a cultural phenomenon, which is aimed at inner spiritual and physical self-development, at the formation of integrity of the individual. Despite the fact that in the context of globalization, commercialization of sports is increasing, role and importance of individual in sports and realization of the possibilities of selfdevelopment are increasing, to exist in the world of sports means to use their potential for self-development and realization of both the interests of sports and those of the individual. In our opinion, this is the return of man to himself, the realization of his immanent forces inherent in man, the realization of the spirit of inner subjectivity. All this testifies to the fact that today the social and cultural value of sports is increasing, that playing sports is becoming prestigious, that sports are beginning to be attached to human values, which carry a humane goal [7].

Optimization of the human potential of sport as a condition for the formation of the sports paradigm of society in the context of globalization is that sport is a socioaxiological system, based on humanistic values that are oriented towards the development of creative (c) Bilohur V. E., 2018 potential, that the athlete's reward should express patriotic feelings, athlete's pride, the basis of which achievement of high results and records due to the development of its physical strength and capabilities. In the context of globalization, sport includes the contradictions between freedom and violence, ethical problems of doping, social and economic inequality, which must be overcome. In sports, everyone believes in the innate talent, talent of man from nature, the thinking of an athlete aimed at winning, the development of personal sports management. Sport as a socioaxiological system is a sphere of humanity, which includes social ideals and values, personal intentions, which require new approaches to the analysis of sport as the most important sphere of human activity. It is the optimization of the humane potential of sports as a condition for the formation of the sports paradigm of society in the context of globalization that can explain and solve many problems of sports, which are based on the relationship between culture and sports, culture and society, culture and personality[8].

The nature of interaction in the modern conditions of nature, society and man more and more confirms the conclusion that the essence of human nature is characterized by the unceasing aspiration of man to go beyond himself and his world, even trying to circumvent the laws of nature and history. This characteristic feature of human nature, which is the regularity of the formation of its relations with the surrounding world, 
is associated with the anthropological dimensions of sport as the implementation of the generic nature of man. Sport is always a person's involvement in the created and created, this way of being an individual in the sports world in his individual manifestations, in which a person realizes his endless possibilities, his incompleteness and openness. Sport is an outflank of human existence, in the context of which the expediency of everyday life is overcome. Sporting human intentions are developed and cultivated by its sentimental demands, without the disclosure of which it is impossible to understand the anthropological dimensions of humandimensional sport. O. Huxley has not accidentally expressed the opinion that sport can perform both creative and destructive functions in society, and in the multicultural society they are increasingly confirmed in practice. According to Blenchard, $\mathrm{K}$. aggressive instincts have always been an integral part of human nature, sports relations are an expression of pressure, power, subjugation and privileges that in general violates the anthropological dimensions of sport, as a tool for sublimation of aggression acts.

By the way, in our research first of all in social sport space applied new human-dimensionality paradigm, which allows you to identify the degree of trends correlation in sport and development of human essential forces as their generic entity, aimed at forming a holistic personality of the athlete [9].
All this allows us to deepen theoretical ideas about the main characteristics of sport phenomena, to more accurately determine the components and trends of the development of contemporary sports thinking and practice of sport, the conceptualization of modern knowledge about sport, based on anthropological principles. Adequate comprehension of this, sufficiently determining block of problems, allows us to understand peculiarities of current stage of sports development, confrontation peculiarities of ideological settings, values, regulations and practices that characterize sports life today. Therefore, the very logic of problems, features and trends in the development of sport as a specific social practice requires the use of a broader context socio-political and sociocultural, based on the concept of humandimensionality. The dynamically growing crisis of modern porcupine, the essence of which lies in a violation tendency of human dimension limits is a sufficiently large motivating factor in the research of this phenomena, determining the prospects for its development and identifying those means whose application allows the humanization of sport.

Nowadays, the importance of such anthropology as sports, which studies the patterns of morphological and functional changes occurring the human body under the influence of sports activities, increases? Its main method - the method of anthropometry or somatometry - is the measurement of a living person, for

Self-realisation of personality in sport as the main megatrend of sport formation paradigm in conditions of globalization: socioanthropological measurements 
whom the important role played by such sciences as anatomy and physiology, genetics and psychology, biometrics and biophysics. Nowadays, without anthropology, neither medicine nor archeology is conceivable [8].

We are investigating problems associated with analysis of a man in modern sports and correlation degree between various aspects of its nature in dichotomy "biological-social", "physical-spiritual", which also affects the development of generic nature of a man. The domestic philosophy of sport tries to overcome narrow limits of the attitude towards individual only as a carrier of physical qualities only based on the idea of biosocial human nature, but also the ability to form a person as a spiritual and bodily integrity.

Therefore, in our opinion, the place of sport in the ontological space of culture is determined, above all, by its ability to identify the limits of the maximum realization of the possibilities that human solidity possesses.

At the same time, when determining the socio-anthropological principles of sport, is better to approach the realization of needs and motivations, so much to go beyond the necessary limits of possibilities laying human-dimensionality moments. Therefore, it must be acknowledged that in sport possibilities implementing humandimensional function of culture laid down. Analysis of literature has shown that nowadays sport comprehension of human nature is increasingly breached by narrow (C) Bilohur V. E., 2018 horizon of purely terrestrial, natural and animal existence of man, entering into the space of more profound interpretations the implementation the generic nature of man.

Modern sport came up to the discovery of the limits of humandimensionality, since it gives maximum load for the body and spirit, which allows one to consider it as one of the ranges of the anthropological boundary (Khoruzhogo, S.). Outside the boundary - an exit to another dimension in relation to normal human life: in death, injury, the crisis of self-consciousness.

Violation of humandimensionality introduces into the sport an element of inhumanity, the destruction of all human, the generation of negative incentives for the development of personality. The spirit of adversity simulates the situation of human self-determination, which is carried out in the system "I am other" or "I am the other", so selfdetermination is possible if "I" singles its indicators with others. Today, as never before, the social value of sport increases and this kind of activity becomes more and more prestigious [9].

Self-realization of the person in sport as the main megatrend of global society goes to the concept of human race measure, which is linked between humanitarian science, anthroponomy and social science anthropology. If anthropology, in principle, is intended to study the generic qualities of mankind, then anthroponomy examines the qualities of the human individual (in our understanding of the athlete). The dialectical bond of the 
general and the individual makes it possible to note that the qualities of the human race (general) are inherent in every human individual (separate). The study of human species involves the discovery and justification of such human qualities, which powers its essential generic and social constants, characterize each person. The study of a set of qualities, signs the human race makes it possible to identify four such social constants: consciousness, language, communication and activity, since all other qualities are not generic, or are modes, types of named as essential qualities [10].

In our opinion, it is necessary to distinguish four generic features of a person, aimed at revealing its generic nature:

1) consciousness as a property of an athlete's brain to reflect reality in sports images and language, which serves as a regulator of human activity at a sports level and has a different volume;

2) language of the athlete as a sign system for expressing thoughts, implementing social communications and creative thinking, performing functions - $\quad$ expressive, communicative, creative and memorable;

3) communication as the entire set of communication athlete, determined by information, praxeology and axiological relations, expressing three subsystems of social experience of mankind - knowledge, skills and social settings;

4) activity as an expedient interaction of a person with a substantive sports world, based on consciousness, language and communication, representing the integrative quality of a person and uniting in a functional complex.

Self-realization of personality in sport as the main megatrend of global society in the anthropological foundations of the study includes eight components - subject, object, means, process, conditions, result, system and environment. Sports activity with the athlete's mind, language and communication [11].

Characteristic feature of human nature, which basis anthropological foundations of human-dimensional sport, raises problem of transgressed creativity dualism, which, on the one hand, is positive, as it extends the sphere of self-realization of man and its generic entity, and on the other works negatively - so how often destroys the human nature and promotes the release of destructive intentions of man. It is in this that the foundational basis of world's dimension people problem in its anthropological principles, formed by man in the form of various social practices, one of which is sport [12].

Socio-anthropological principles of human-dimensional sport are a generalized characteristic of individuality, which has a way of its concrete existence, because human origin is always individual. Humandimensional sport as a way of revealing its anthropological foundations testifies to how man possessed the natural and cultural (artificial) world; it possessed not only its essential forces, but also the factors

Self-realisation of personality in sport as the main megatrend of sport formation paradigm in conditions of globalization: socioanthropological measurements 
of its development, which are in sports.

However, socio-anthropological measurements of humandimensionality include two planes:

1) the world considered as a reality, limited by human possibilities;

2) the world, which is considered as the limitations of the person himself, is connected with the infinite possibilities (the term "sports capacity" as a receptacle of physical and spiritual forces).

Therefore, an essential aspect of human-dimensionality in field of sport is determination of correlation degree between extremely expressed, natural data and culturally modified bodily personal properties, possibilities of its operational intelligence, as well as, psychological characteristics of individual (will, endurance, patience, endurance) and moral qualities (sense of responsibility, friendship, duty), correlated with the principles of harmony and integrity of man.

Conclusions from the research and perspectives of further exploration in this direction

Sport begins act as a way of attracting other countries to the values of industrial and postindustrial civilizations. The type of athlete that represents international type, symbolizing advantages of civilization, is also changing.

The main threat that can arise before a man is the menace of humanization into non-human dimension, in which man, nature and society are confronted. Therefore, the basis of the socio-anthropological principles of sport is a modern man that should find a chance and understand himself, to form socially realized spiritual space and physical searches, aimed to individual achievement of sports results.

\section{REFERENCES}

1. Bilohur, V. (2013). Formation of the Concept of Contemporary Sports as a System of Value Orientations of Youth in the Conditions of Globalization. Gilea: Scientific Bulletin, 75, 326-328.

2. Vizitei, N. (1980). The social nature of modern sport. Shtiintsa, 84.

3. Vizitei N. (1986). Physical culture and sport as a social phenomenon. Chisinau: Shtiintsa, 160.

4. Voronkova, V. (2015). The civil society as a paradigm, concept and social construct philosophical discourse. Philosophy and Cosmology, 15 (1), 198-215.

5. Morgan, W. J. (2003). The Philosophy of Sport: A Historical and Conceptual Overview and a Conjecture regarding its Future. Handbook of Sports Studies, 205-213. doi: https://doi.org/10.4135/9781848608382.n12

6. Hambrecht, H. U. (2012). Praise sporting beauty. Kyiv: Spirit and Letter, 216.

7. Edensor, T. (2002). National Identity, Popular Culture and Everyday Life. Oxford-New York. doi: https://doi.org/10.5040/9781474215305

8. Ibrahimov, M. (2011). "Philosophy of Sport": Will a fruitful philosophy in the field of sports? Young sports science of Ukraine, 4, 54.

9. Holowchak, M., Reid, H. (2011). Aretism: an ancient sports philosophy for the modern sports world. Lanham, Md.: Lexington Books, 15-16.

10. Olexenko, R. (2017). Formation of the creativepersonality concept as a factor of the creative knowledge economy in theconditions of globalization. Humanitarian Bulletin of 
Zaporozhye State Engineering Academy, 71, 118-126. doi: https://doi.org/10.30839/20727941.2017.124895

11. Mechikoff, R., Estes, S. (2006). A history and philosophy of sport and physical education: from ancient civilizations to the modern world. Boston, Mass: McGraw-Hill, 12.

12. Scott, R. (2005). Practical philosophy of sport and physical activity. Champaign, IL: Human Kinetics, 91.

БІЛОГУР, В. Є. - доктор філософських наук, професор, завідувач кафедри теорії і методики фізичного виховання та спортивних дисциплін, Мелітопольський державний педагогічний університет імені Богдана Хмельницького (Мелітополь, Україна)

E-mail: bilovlada@gmail.com, ORCID: 0000-0001-9041-7050

\section{САМОРЕАЛІЗАЦІЯ ОСОБИСТОСТІ У СПОРТІ ЯК ГОЛОВНИЙ МЕГАТРЕНД ФОРМУВАННЯ СПОРТИВНОӤ ПАРАДИГМИ В УМОВАХ ГЛОБАЛІЗАЦЇ̈: СОЦІОАНТРОПОЛОГІЧНІ ВИМІРИ}

Анотація. Актуальність дослідження проблеми самореалізації особистості у спорті як головний мегатренд є специфічною особливістю глобалізації, в контексті якої малодослідженими є соціоантропологічні виміри, пов'язані з людиною. Ця проблема виникає тому, що починається переосмислюватися феномен людини як суб'єкта спортивної діяльності. При цьому спортивна парадигма в умовах глобалізації починає переосмислюватися, так як має свої плюси і мінуси. Мета дослідження концептуалізація самореалізації особистості у спорті як головний мегатренд глобального суспільства в контексті соціоантропологічних вимірів. Завдання дослідження: вивчення проблем управління спортом, що детермінуються масштабними трансформаціями сучасного соціуму; дослідження принципів, на основі яких відбувається формування спортивної парадигми в умовах глобалізації; аналіз реалізації можливостей саморозвитку людини у світі спорту в умовах глобалізації; формування нової спортивної парадигми, яка дозволяє виявити міру співвіднесеності тенденцій спорту і потреб у розвитку сутнісних сил людини як їх родової сутності. Аналіз останніх досліджень і публікацій, з яких започатковано розв'язання даної проблеми: використання статей авторів Vizitei N. (1986), Voronkova, V. (2015)., Edensor, T. (2002)., Hambrecht, H. U. (2012), Holowchak, M., Reid H. (2011), Mechikoff, R. (2006), Morgan, W. J. (2003), Olexenko, R. (2017), Scott, R. (2005), в яких вирішуються проблеми людини та іiї самореалізації у світі спорту та соціоантропологічні засади, які $\epsilon$ малодослідженими у сфері спорту. Методологія дослідження - антропологічний та соціоаксіологічний методи, що сприяють проникненню в світ спортивної людини, еволюції спортивної парадигми в умовах глобалізації, позначеною багатьма проблемами людино вимірності, так як спорт пов'язаний і з комерціалізацією. Наукова новизна - у виявленні проблем глобалізації, що впливають на спортивну людину, спортивну діяльність та в цілому на світ спорту. Результати дослідження : самореалізація людини у спорті в умовах глобалізації, що представляє якісну характеристику спортивного світу, започатковану різноманітними спортивними практиками спортивного світу та розкриває рух до інтеграції та цілісності. Висновок концепція самореалізації особистості у спорті як головний мегатренд формування спортивної парадигми в умовах глобалізації потребують іiї доповнення соціоантропологічними виміри

Ключові слова: самореалізація особистості, мегатренд, глобалізація, спорт, управління спортом, спортивна парадигма, соціоантропологічні виміри, людиновимірність спорту

Self-realisation of personality in sport as the main megatrend of sport formation paradigm in conditions of globalization: socioanthropological measurements 
БИЛОГУР, В. Е. - доктор философских наук, профессор, заведующая кафедрой теории и методики физического воспитания и спортивных дисциплин, Мелитопольский государственный педагогический университет имени Богдана Хмельницкого (Мелитополь, Украина)

E-mail: bilovlada@gmail.com, ORCID: 0000-0001-9041-7050

\section{САМОРЕАЛИЗАЦИЯ ЛИЧНОСТИ В СПОРТЕ КАК ГЛАВНЫЙ МЕГАТРЕНД ФОРМИРОВАНИЯ СПОРТИВНОЙ ПАРАДИГМЫ В УСЛОВИЯХ ГЛОБАЛИЗАЦИИ: СОЦИОАНТРОПОЛОГИЧЕСКИЕ ИЗМЕРЕНИЯ}

Аннотация. Актуальность исследования проблемы самореализации личности в спорте как основной мегатренд является специфической особенностью глобализации, в контексте которой малоисследованными являюся социоантропологические измерения, связанные с человеком. Эта проблема возникает потому, что начинает переосмысливаться феномен человека как субъект спортивной деятельности. При этом спортивная парадигма в условиях глобализации начинает переосмысливаться, так как имеет свои плюсы и минусы. Цель исследования - концептуализация самореализации личности в спорте как главный мегатренд глобального общества в контексте социоантропологических измерений. Задача исследования: изучение проблем управления спортом, что определяется масштабными трансформациями современного социума; исследование принципов, на основе которых происходит формирование спортивной парадигмы в условиях глобализации; анализ реализации возможностей саморазвития человека в мире спорта в условиях глобализации; формирования новой спортивной парадигмы, которая позволяет выявить степень соотнесенности тенденций спорта и потребностей в развитии сущностных сил человека как их родовой сущности. Анализ последних исследований и публикаций, из которых начато решение данной проблемы: использование статей авторов Vizitei N. (1986), Voronkova, V. (2015)., Edensor, T. (2002)., Hambrecht, H. U. (2012), Holowchak, M., Reid H. (2011), Mechikoff, R. (2006), Morgan, W. J. (2003), Olexenko, R. (2017), Scott, R. (2005), в которых решаются проблемы человека и его самореализации в мире спорта и социоантропологические принципы, которые являются мало исследуемыми в сфере спорта. Методология исследования - антропологический и социоаксиологический методы, способствующие проникновению мира спортсмена, эволюции спортивной парадигмы в условиях глобализации, обозначенной многими проблемами человечества, так как спорт связан и с коммерциализацией. Научная новизна - в выявлении проблем глобализации, влияющих на спортивную жизнь человека, спортивную деятельность и в целом на мир спорта. Результаты исследования: самореализация человека в спорте в условиях глобализации представляет качественную характеристику спортивного мира, основанную разнообразными спортивными практиками спортивного мира, и раскрывает движение к интеграции и целостности. Выводы - концепция самореализации личности в спорте как главный мегатренд формирования спортивной парадигмы в условиях глобализации требует eе дополнительных социоантропологических измерений.

Ключевые слова: самореализация личности, мегатренд, глобализация, спорт, управление спортом, спортивная парадигма, социоантропологические измерения, человечность спорта.

Стаття рекомендована до публікачії д.філософ.н., проф. І.С.Рижсовою (Запоріжжся, Україна)

Надійшла до редколегіï: 11.11.2018 p. Прийнята до друку: 16.11.2018 p. 